\title{
INSAMLINGSPROGRAM - GRUNDEN FÖR PLANMÄSSIGA SAMLINGAR
}

Juhani Kostet

I Finland finns det för närvarande över 900 museer, varav 130 har fasta tjänster och andra anställningar, varav 583 forutsätter utbildning $i$ ett museifack. I landskapet Egentliga Finland - vars insamlingsansvar jag skall äterkomma till - har vi i 59 kommuner över etthundra samlingar som kallar sig museer och har ett offentligt samfund som buvudman. Dessutom finns det 55 privata museer eller samlingar. I Finland är det bara Österbotten som har ett lika tätt nät av museer som Egentliga Finland. Antalet museer $i$ Finland är exceptionellt stort jämfört med mänga andra länderl, vilket helt enkelt beror $p a ̈$, att vi har en sä lös och tolerant definition av begreppet museum.

Under museidagarna i Borgå våren 1996 konstaterade intendent Marketta Tamminen i sitt anförande helt cyniskt, att det finska museet är:

1) ett alternativ till soptippen,

2) ett ställe där man kan ta sig en kopp kaffe,

3) en träffpunkt eller

4) ett bra sätt att avgöra arvstvister.

Intendent Tamminen belyste också problematiken kring begreppet museum. Kan vem som helst ge sin föremålssamling, eller som Tamminen uttryckte det sin "skräphög", namnet museum? För att ge museet större betydelse, betona dess syfte och höja dess status föreslog Tamminen begreppet «registrerat museum». Precis som man hos oss kontrollerar bildandet av nya föreningar och partier, borde man också kontrollera bruket av benämningen «museum». Museet har ju en central samhällelig uppgift, museiarbetet övervakas delvis av samhället och finansieras delvis med allmänna medel. Detta åter kan ha en viss betydelse, när insamlingsansvaret skall specificeras.

\section{LUSTEN ATT SAMLA}

Samlingarna och museerna baserar sig på människans lust att samla. På samlarstadiet ville människan ta till vara minnen, heliga föremål, kraftfulla föremål, före- 
54 målsenergi. Fast den moderna människans handlande styrs av andra faktorer, är det i alla fall samma instinkt som får henne att samla. ${ }^{2}$ De flesta kulturhistoriska museer har uppstått som ett resultat av en flitig samlares arbete under flera årtionden, och än i dag erbjuds museerna stora privata samlingar, numera ofta till ett högt pris. Ibland är de här samlingarna av oerhört stort värde för museet, men lika ofta är de musealt sett betydelselösa. De har ingenting att berätta. ${ }^{3}$ Susan Pearce har indelat samlandet i tre grupper:

1) samlandet av minnen,

2) fetischistiskt samlande och

3) systematiskt samlande.

Tillvaratagandet $\mathrm{i}$ ett modernt museum åter styrs av tre huvudprinciper:

1) Ett museum kan inte ta till vara alla föremål som finns.

2) Insamlandet måste vara selektivt.

3) Föremålen måste avspegla den faktiska verkligheten. ${ }^{4}$

Eftersom insamlandet måste vara selektivt, vilket betyder att bara några föremål bland alla de otaliga alternativen kan tas till vara, så kan man fråga sig, vem som sist och slutligen träffar valet. Det slutliga urvalet påverkas också av många faktorer som är oberoende av den som ansvarar för insamlandet:

1) slumpen,

2) donatorn,

3) priset,

4) föremålets storlek,

5) den för tillfället dominerande nationella kulturen, som styrs av symboler, värderingar och historiesyn, samt

6) museets traditioner. ${ }^{5}$
Till en början var inrättandet av museer beroende av individer. Och det var grundaren som bestämde insamlingens inriktning. När museisamlingarna började utökas och vårdas systematiskt, måste man reda ut, vilket museets ändamål sist och slutligen var. Om museet i fråga skulle vara ett landskapsmuseum, måste det utvecklas så, att regionens historiska utveckling blev så väl belyst som möjligt. Om det åter skulle vara ett lokalt museum, kunde samlingen vara mindre och begränsas till den ifrågavarande kommunens eller byns historia. Men i alla fall måste man se till, att det inte på museet samlades allsköns bråte eller enbart privat personhistoriskt material utan vidare historisk eller estetisk betydelse. Särskilt lokalmuseerna blev ofta «diversedepåer» på grund av bristfällig kontroll. ${ }^{6}$

Museientusiasmen på 1800-talet hade sin grund i att finländarna sökte sina rötter och strävade efter att öka sin självkänsla under förtrycksperioden. Man ansåg det viktigt att ta till vara föremål för framtiden, så att forskarna skulle kunna utnyttja dem och allmänheten beundra dem. ${ }^{7}$ Människans insamlingsverksamhet kan anses ha haft sin grund i behovet av föda, men samlandet fick tydligen mycket snart likartade drag som det har nuförtiden. En mycket stor del av museernas föremål har tagits till vara av ivriga samlare, som ur museisynpunkt varit amatörer. Grundarna av både Nationalmuseum, konstmuseet i Ateneum och många landskapsmuseer drevs av en stark lust att samla konstverk och föremål som de tyckte var intressanta och vackra. ${ }^{8}$ Samlarverksamhet av olika slag är säkert än i dag en av de allra vanligaste fritidssysselsättningarna.?

Museiväsendet av idag har emellertid 


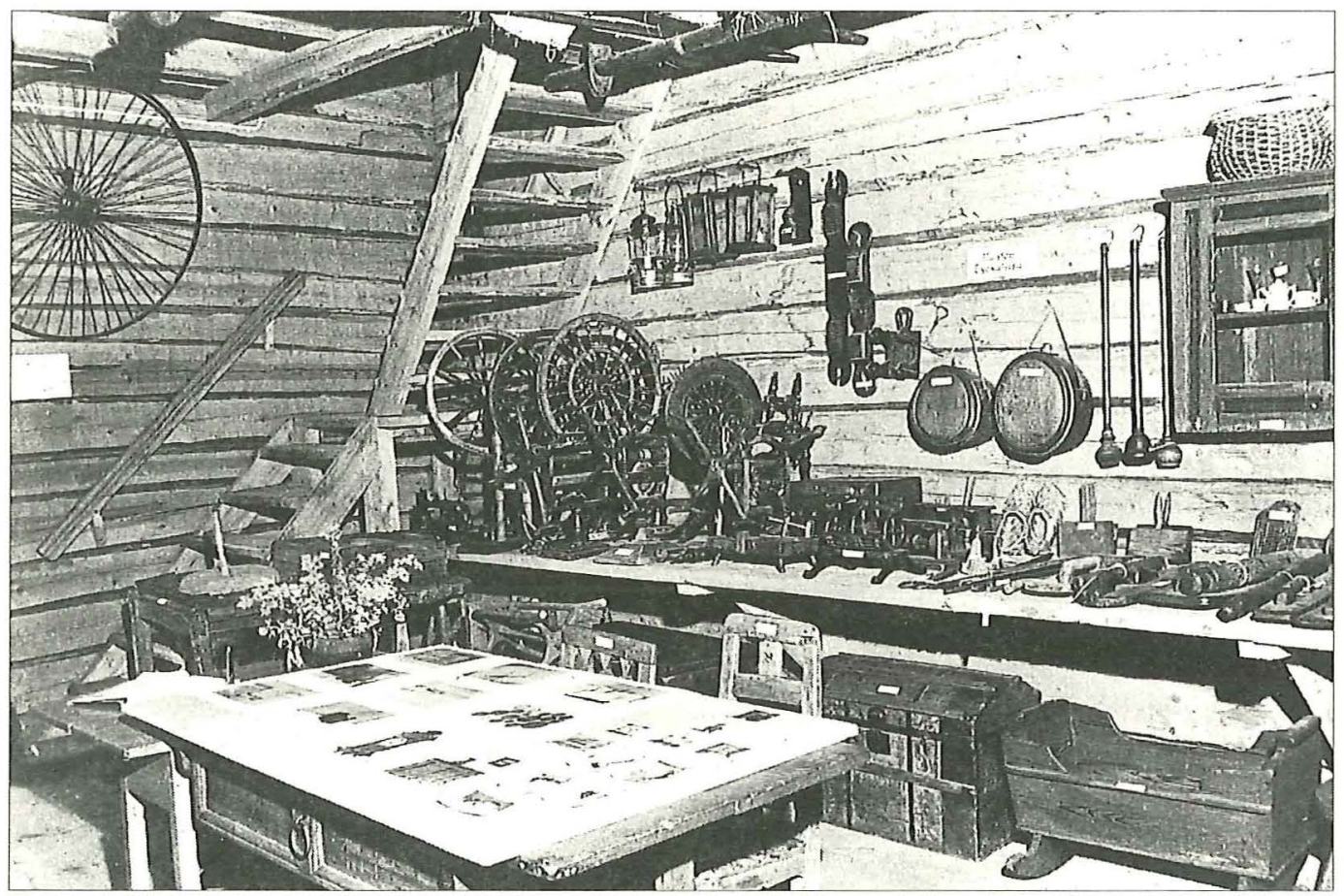

Alla lokalmuseers samlingar är likartade, $i$ allmänhet innefattar de verktyg som ansluter sig till lantbruksnäringarna. Bild: Abo Landskapsmuseum.

stött på nästan oövervinneliga problem. Vår moderna värld producerar enorma mängder av alla slags föremål, av vilka största delen förr eller senare slutar på soptippen, en del tas till vara i museerna och en del går till återvinning. Situationen börjar vara katastrofal, både i museerna och på soptipparna. Museerna kan inte bli soptippar - snarare finns det kanske på museerna en del som skulle kunna slängas på soptippen. Museernas skyldighet att ta till vara människans materiella kultur ställer de samlingsansvariga inför ett svårt problem: vad skall man välja när det gäller dagens "kulturarv»? All systematisk insamling leder till absurditeter. ${ }^{10}$ Charles
Baudelaire ansåg, att loppmarknaden med sin anhopning av nuets reliker är det mest äkta kulturhistoriska museet av alla. Mellan föremål från olika tider, som sammanförts av en slump, uppstår det spänningar, och utgående från dem kan åskådaren associera fritt och på ett skapande sätt. Därför har man till och med framfört tanken, att det är soptippen som är det mest äkta kulturhistoriska museet. På soptippen uppstår ingen sådan monopolisering av minnena som i ett kulturhistoriskt museum. På soptippen ligger det bortslängda livet. Drömmarnas frånsida. På soptippen finns allt det, som man av en eller annan orsak inte vill ge vidare åt 
JUHANI KOSTET

56 kommande generationer. Soptippen berättar sanningen om hur man verkligen levde. $^{11}$

Det finns ytterligare ett markant drag som kännetecknar dagens samhälle. Det sägs, att hela den västliga industrialiserade världen är som besatt av sitt förflutna. När det inte finns någon framtid i sikte, klamrar man sig fast vid den gångna tiden, och det tar sig uttryck bland annat däri, att man flitigt grundar museer och att det privata insamlandet får enorma dimensioner. Enligt Henri Pierre Jeudy grundar sig den väldiga museimanin på rädsla för framtiden, rädsla för den slutliga förintelsen, rädsla för att historien skall ta slut. Därför vill människan rädda alla tecken på kultur, bygga ett musealt universum, som ser ut som ett jättelikt, postkatastrofalt landskap. Man måste hejda tidens gång, man måste fånga tiden. Genom att mumifiera det förgånga och det närvarande tror sig människan nå odödlighet. ${ }^{12} \mathrm{I}$ den västerländska moderna kulturen anser man, att människans liv börjar med födelsen och fortsätter lineärt fram till döden. Både individens och nationens identitet förknippas med den materiella miljön, det vill säga föremålen. Den moderna människan är redan van vid att liv och identitet är liktydigt med att äga en mängd föremål, så van, att hon inte ens kommer att tänka på att det skulle kunna förhålla sig annorlunda. Erich Fromm kallar denna livsform för "ägandets livsform», och dess motsats för "varandets livsform". Den som hyllar ägandets livsform tänker: "Jag är vad jag äger.» Den som hyllar varandets livsform tänker: "Jag är.» ${ }^{13}$ Kärnan i Fromms tanke kommer fram i följande tes: «Om jag är vad jag äger, och det blir kvar efter mig, då är jag ju odödlig.»

Intressant är, att museiväsendet stabiliserade sig i det finländska samhället på 1800talet, då det klassiska ägandets betydelse var som störst men man också hade börjat betona livets andliga faktorer. Och på 1900-talet, när ägandet övergått i allt häftigare konsumtion, har också museientusiasmen och ivern att bevara ökat oerhört. ${ }^{14}$

\section{PLANMÄSSIGT SAMLANDE}

Trots människornas insamlingsiver fördelas ansvaret för tillvaratagandet av den materiella kulturen i stora drag på följande sätt: museerna samlar in föremål, konstverk, naturhistoriska sampel och fotografier, arkiven samlar dokument och manuskript, biblioteken samlar tryckt och audiovisuellt material. Ett gemensamt område blir då de privata arkiven, de tryckta konstverken samt fotografierna och de dokument som hör ihop med föremålssamlingar. ${ }^{15}$ Alla museer är historiska museer, emedan deras samlingar berättar om en gången tid. De kulturhistoriska museerna har tagit till sin uppgift att samla och bevara människans forntid utefter hela skalan, och de har inte $\mathrm{i}$ allmänhet koncentrerat sig på något speciellt. ${ }^{16}$

För att man skall få till stånd en tillfredsställande och täckande samling är det vissa omständigheter som man måste beakta vid tillvaratagandet. Museets insamlingsverksamhet måste vara aktiv. Det betyder, att museet självt bestämmer vad samlingen skall innehålla och vad som skall tas med i den. Att bara ta emot föremål resulterar i otillfredsställande samlingar. ${ }^{17}$ Den mest problematiska frågan är: hur omfattande skall insamlingsverksamheten vara för att vara tillräcklig? Av museiväsendet som helhet förutsätts, att 
en tillräcklig mängd information om människan, samhället och naturen bevaras för kommande generationer, men vilket är det enskilda museets ansvar inom ramen för denna helhet? Regionala och riksomfattande insamlingsprogram skulle vara nyttiga också i det avseendet att de avslöjar luckorna. ${ }^{18}$

Museernas äldsta samlingar har kommit till i enlighet med de för den aktuella tiden typiska insamlingsmetoderna. Förutsättningen för hela insamlingsverksamheten i Finland kan anses ha utgjorts av två faktorer. För det första: i medlet av 1800-talet organiserades som en följd av Otto Donners arbete en stipendiatverksamhet, som bidrog till uppkomsten av de första samlingarna. Stipendiatarbetet blev ett

Abo landskapsmuseums modern textilmagasin. Bild: Abo Landskapsmuseum.

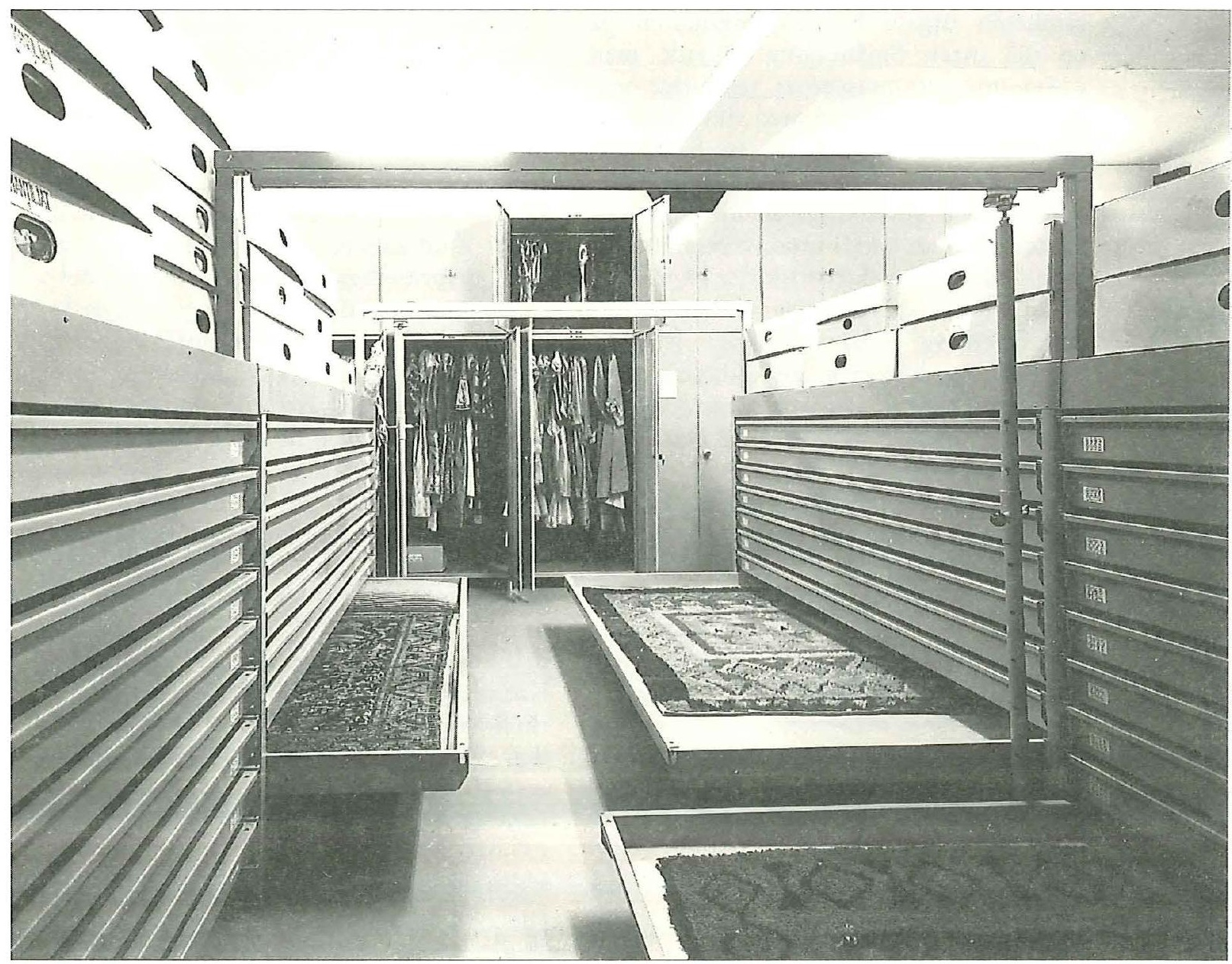


58 slags förebild, som tillämpades på varierande sätt på olika håll i landet. I en del landskap bildades ett ombudsmannanät. Skillnaden mellan stipendiat- och ombudsmannametoden var emellertid den, att stipendiaterna arbetade planmässigt och ombudsmännen slumpmässigt. Också insamlingsresor kunde avkasta goda resultat. För de här resorna uppställdes mål: man samlade in allmogedräkter eller fortskaffningsmedel, verktyg eller skor. Till stöd för den systematiska insamlingsverksamheten utgavs handledningshäften på en del orter. Småningom började man också inse, att museernas samlingar inte bara skulle ha samband med viktiga personer eller lyx. Grundaren av Sagalunds museum på Kimitoön, Oscar Jansson, preenterade vid sekelskiftet en ideell grundprincip för den lokala museiverksamheten. Han hade en kollektivistisk syn på världen och ansåg, att den samtida "officiella» historiesynen var felaktig. Enligt Janssons mening var historien inte liktydig med furstarnas och överklassens historia och fick inte heller presenteras på detta sätt. Bonden var den som skapat utvecklingen. Också bondens historia måste sålunda utredas och presenteras. Det var massorna som var viktiga; de så kallade hjältarnas andel i skeendena var bara en chimär. Vägledd av denna historieuppfattning började Jansson samla in föremål med anknytning till landsbygdens befolkning. ${ }^{19}$

Den oerhörda mängden av fenomen och föremål $\mathrm{i}$ vår egen tid har ställt museerna inför nya utmaningar och val. Vad skall man ta till vara, vad skall man inte ta till vara? I medlet av 1980-talet tog museiverket i Finland initiativ till en fördelning mellan landskapsmuseerna av ansvaret för forskningen och dokumenteringen. Man ville utarbeta ett riksomfattande insamlingsprogram som skulle styra insamlingen av den materiella kulturen och fördela ansvaret mellan landskapsmuseerna i syfte att trygga en täckande insamling. Grunden för det riksomfattande insamlingsprogrammet var - och är alltjämt de i början av 1980-talet fastslagna verksamhetsområdena för landets landskapsmuseer. ${ }^{20}$ Områdena är 20 till antalet. En annan utgångspunkt för ansvarsfördelningen är det nät av specialmuseer som har uppstått i vårt land. De här museerna skall givetvis ta ansvaret för insamlingen inom sitt eget konkreta specialområde. På så sätt befrias de så kallade allmänna museerna från vissa områden av den materiella kulturen. Indelningen grundar sig på en indelning i kulturområden, som dels följer landskapen, dels kulturområdena. Den ursprungliga meningen med indelningen var att effektivera rådgivningen åt och handledningen av lokalmuseerna samt centralregistreringen av samlingarna.

Tanken på ansvarsfördelningsområden för insamlingen och dokumenteringen var emellertid inte då ny. Redan i början av vårt sekel diskuterades en arbetsfördelning mellan våra museer. De etnologiska föremålen ansågs höra hemma i lokalmuseerna och de fornhistoriska föremålen i centralmuseet. Noggranna direktiv för arbetsfördelningen gav J. Lukkarinen i tidskriften Kotiseutu år 1912. I landsbygdsmuseerna skulle man ha etnologiska samlingar: kläder, verktyg, fortskaffningsmedel, fiskeoch jaktredskap, kärl och så vidare, och varje grupp skulle vara så fullständig som möjligt. Målet var att ge en korrekt bild av kulturen under en viss tid. K. Kallio åter anförde, att man i sockenmuseerna också skulle ha en samling jordbruksverktyg. ${ }^{21}$ 
Museiförbundets centralstyrelse sände redan år 1933 en enkät till museerna, med följande frågor:

1) Vilket geografiskt område inriktar sig ert museums föremålsinsamling på? På vilket område insamlar ni nu föremål?

2) Vilket område vill ert museum speciellt företräda och skildra i utställningarna?

3) Vilka andra museer verkar inom samma område som ert museum?

4) Hur skulle ni vilja begränsa ert verksamhetsområde?

5) Vilka för er trakt typiska föremålsgrupper eller vilka specialsynpunkter beaktar ert museum i sin insamlingsverksamhet?

6) Hurdan uppgifts- och områdesfördelning med andra museer på samma område eller mellan museerna i landskapet överhuvudtaget anser ni önskvärd i syfte att undvika inbördes konkurrens?

7) Anser ni att föremålsbyte med andra museer är möjligt?

8) Är ni helt eller delvis emot en områdesindelning?

\section{DET MUSEIPOLITISKA PROGRAMMET 1981}

I museiverkets museipolitiska program 1981 konstaterades, att problematiken kring museisamlingarna varit den viktigaste frågan redan i museiverksamhetens tidiga skeden. Men ett nytt problem var frågan om hur museerna skulle kunna svara för tillvaratagandet av den materiella kulturen under den nära förgångna tiden och nutiden. Som en lösning såg man det interna samarbetet, som man ville genomföra enligt en plan som uppgjordes i medlet av 1980-talet. ${ }^{22}$ Det konstaterades om insamlingen och ansvarsfrågorna, att museerna tillsammans med de övriga tillvaratagande institutionerna skall svara för att en tillräcklig mängd information om människan, samhället och naturen bevaras för framtiden och också för att betjäna det nuvarande samhället. Som problematiska frågor inom museernas insamlingsverksamhet sågs arbetsfördelningen mellan museerna och de andra tillvaratagande institutionerna, formerna för den museala insamlingen samt insamlingens innehållsliga och tidsmässiga täckning. Praktiska problem konstaterades vara förknippade med planeringen och koordineringen av en vederhäftig insamling på riksplanet samt utvecklandet av materialhanteringen - bland annat katalogiseringen - så att den motsvarar den allt större mängden av material som tillvaratas. ${ }^{23}$ I programmet konstaterades vidare, att man inte längre kan bevara den industriella tiden, dvs. den nära förgångna och nutiden, bara genom att ta till vara föremål på museerna, redan därför att det produceras en så stor mängd föremål. Där konstaterades också, att särskilt bevarandet av den nära förgångna och nutiden tvingat museerna att omvärdera de traditionella tillvaratagningsmetoderna och att det inte är möjligt att bevara en bild av livet och samhället under innevarande decennium bara genom att bevara boendeformer eller ta till vara vardagliga bruksföremål. Museerna måste utvidga sitt traditionella material, utveckla ett urvalssystem på basis av olika undersökningar samt utnyttja de icke-föremålsliga tillvaratagningssätt som fortlöpande utarbetas. ${ }^{24}$ Den enkät som riktades till landskapsmuseerna år 1991 visar, att inte heller landskapsmuseerna har någon bred, mångsidig och planmässig insamlingsverksamhet, för 
60 att inte tala om att planmässigheten skulle täcka hela landskapet. I museerna tycks man också ha glömt samlingarnas uppkomsthistoria, för de flesta av landskapsmuseerna meddelade, att deras samlingar till 90 \% uppstått genom donationer, men här ingår då givetvis de donationer som man fått i samband med insamlingsarbetet.

Fördelningen av insamlingsansvaret och dokumenteringen av såväl den nära förgångna tiden som nutiden blev viktiga diskussionsämnen senast på 1980-talet. En av grundtankarna i Museiverkets museipolitiska program och den därpåföljande fördelningen mellan museerna av forsknings- och insamlingsansvaret var, att dokumentering av den nära förgångna tiden och nutiden skulle inledas $\mathrm{i}$ vårt land. Programmet var emellertid bristfälligt, idéfattigt, metodlöst och oorganiserat. Annorlunda var det emellertid i vårt västra grannland. Som ett resultat av flera års planering färdigställdes i Sverige år 1977 ett program för dokumentationen av samtiden och en fördelning av ansvarsområdena mellan landets kulturhistoriska museer och specialmuseer. Programmet fick namnet SAMDOK (Samordning av samtidsdokumentation vid kulturhistoriska museer) och omfattade 70 museer eller andra institutioner med dokumenteringsverksamhet. Dessa arbetar alltså med dokumentering av samtiden eller den nära förgångna tiden inom ramen för programmet och inom den temakrets som de har valt. Syftet med programmet är att trygga dokumenteringen av kulturhelheten och att förhindra dubbelarbete. ${ }^{25}$

SAMDOK-arbetets utveckling kan numera följas i publikationen «Samtid \& museer» som utges av SAMDOK-sekretariatet vid Nordiska museet.
En viktig fråga när det gäller museisamlingarna är deras täckning. Bristerna härvidlag är ofta mycket stora och gäller speciellt dokumenteringen av den nära förgångna tiden, där man än så länge bara befinner sig i inledningsskedet. Bristen på strategier är iögonenfallande stor och problemen enorma. Föremålsströmmen är outsinlig: man kan säga att det $i$ en järnhandel finns ca 50000 föremål, medan dagligvaruhandeln introducerar 1600 nya produkter varje år! Vad skall man bevara av allt detta? Oviljan att ta itu med problemet leder ofta till brister som sedan inte kan avhjälpas. Vid insamlingen tänker man kanske, att tiden gör sin utgallring bland föremålen. Bilden av det förgångna är emellertid inte längre densamma, ifall de vardagliga bruksföremålen inte finns med. Dessutom är det dyrt och frustrerande att insamla sådana först efter 50 år. ${ }^{26}$

Insamling kan i princip bedrivas på två sätt:

1) genom att komplettera samlingarna med föremål som tagits ur bruk,

2) genom dokumentering av den nära förgångna tiden och nutiden.

I det första fallet behövs en grundlig inventering av samlingarna i syfte att klarlägga de reella sociala och funktionella samt tidsmässiga och regionala bristerna. ${ }^{27}$ I våra kulturhistoriska museer har man också först under de senaste decennierna insett, att de gamla samlingarna trots allt vuxit slumpmässigt och passivt. ${ }^{27}$ Enligt enkäten till landskapsmuseerna har samlingarna vuxit på tre sätt. Här utgör donationerna den största och viktigaste gruppen. Enligt museernas egen uppskattning har $87 \%$ av samlingarna erhållits som 
donationer. Bara några procent har erhållits som resultat av planmässig insamling och en lika liten del har planenligt inköpts. ${ }^{29}$ Fast resultatet av de gamla insamlingsmetoderna kan kritiseras vad planmässigheten beträffar, var det i varje fall fråga om planmässigt insamlingsarbete. Men planmässighetens grunder och mål var andra än i dag. Till exempel Samuli Paulaharjus insamlingsarbete i norra Finland och Lappland hade ett klart syfte: att anskaffa föremål med anknytning till den samiska kulturen. På samma sätt kan man hitta exempel på insamling rörande tjärbränning, stockflottning och så vidare. Men givetvis fanns det också slumpmässighet $\mathrm{i}$ det tidiga insamlingsarbetet. När vaktmästare August Laaksonen vid Åbo stads historiska museum skickades ut i landskapet för att samla in föremål, ombads han rätt och slätt begränsa sig till allmogekulturen. De stipendiater som jag tidigare nämnde gavs rätt klara gränser för sitt insamlingsarbete, men ombudsmannasystemet resulterade säkert i slumpmässiga samlingar. Den bassamling som hopbragts i samband med inrättandet av ett museum har i varje fall varit riktningsgivande också för den senare insamlingslinjen: den gamla samlingen har utökats och kompletterats.

Ett museum skapar sin linje med ett insamlingsprogram, som kan sägas ha fyra huvudpunkter. Man måste beakta

1) föremålens allmänna karaktär,

2) föremålens typiska karaktär,

3) föremålens betydelse, och

4) den regionala täckningen.

Det måste finnas ett explicit insamlingsprogram: man måste veta vad man samlar, och man måste dra gränser för samlingarna. Den här planmässigheten har en mängd delfaktorer, som man måste kunna ekonomiska planeringen, som är beroende av takorganisationens ekonomiska utveckling och planering. För det andra har vi den långsiktiga respektive kortsiktiga insamlingsplaneringen, som senast i kortsiktsskedet måste bindas vid de ekonomiska planerna och verksamhetsplanerna. Sedan har vi utställningsplaneringen, som är bunden vid verksamhetsplaneringen, budgeten och insamlingsplanerna. Och forsknings- och dokumenteringsplanerna åter skall betjäna hela den ovannämnda verksamheten. Om man följer de här principerna, kan man ur samlingarna lätt utesluta de föremål som inte gäller det aktuella området, som passar bättre i någon annan samling, som redan finns i samlingarna eller som saknar betydelse.

Utarbetandet av en insamlingsplan förutsätter många slags förberedelser. För det första krävs en genomgripande inventering av den redan existerande samlingen. På basis av inventeringen kan man sedan konstatera vilka luckor det finns, med beaktande av sociala, geografiska, kronologiska och verksamhetsmässiga synpunkter. En analys av samlingen ger viktig information för insamlingsarbetet. För de flesta samlingar gäller, att föremål som företräder de lägre samhällsklasserna är underrepresenterade, fast de i princip är de vanligaste. Då fyller samlingen inte kravet på representativitet och täckning. Också vad den tidsmässiga täckningen beträffar konstateras vanligen brister vid analysen. Hela tidsperioder, särskilt äldre, kan ha blivit obeaktade. Också den geografiska täckningen varierar. Kravet på geografisk täckning är emellertid ofta svårt att leva upp till. I samlingarna finns vanligen en hel 
JUHANI KOSTET

62

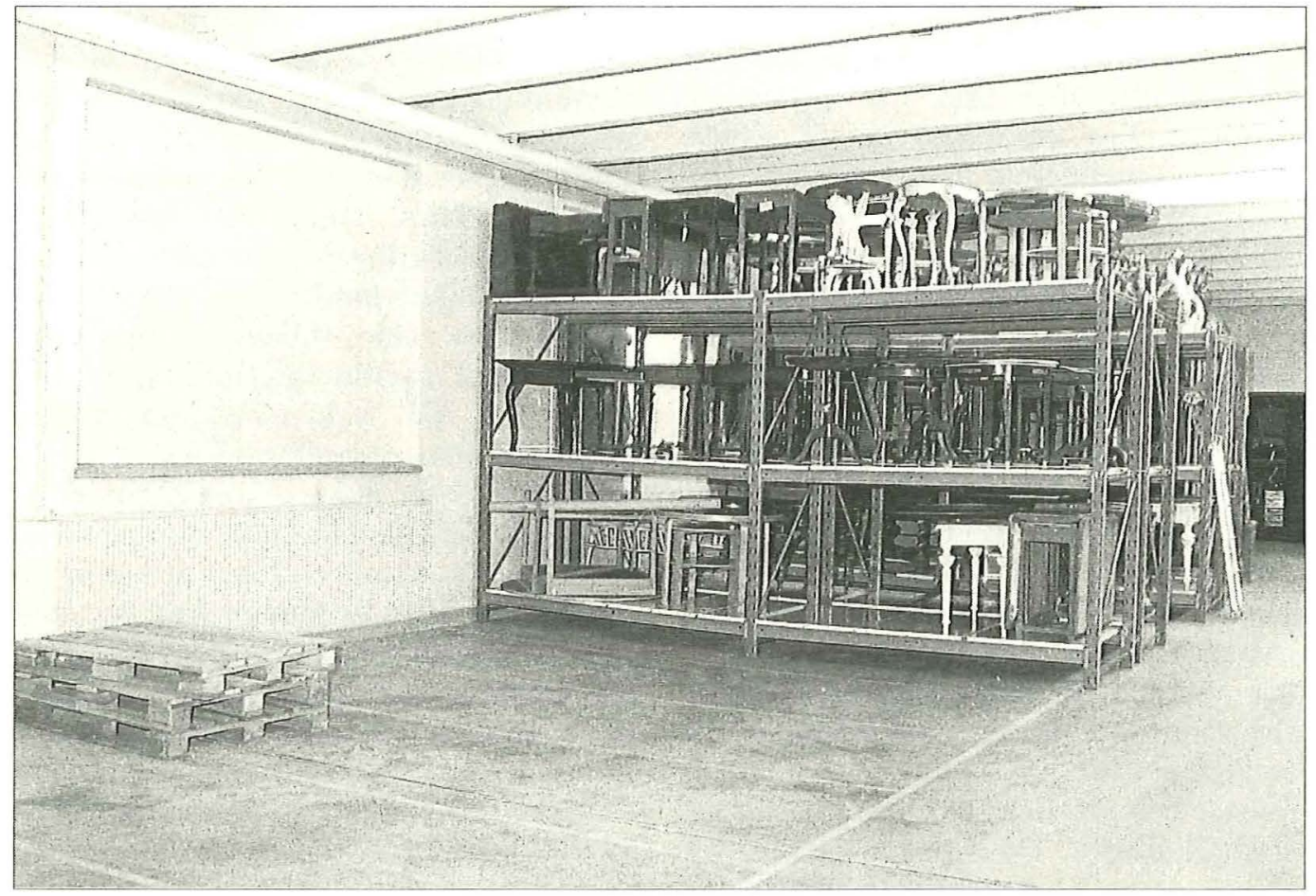

Möbelsamlingarna är en av de viktigaste delarna av finska landskapmuseer.

Abo landskapsmuseums möbelmagasin. Bild: Abo Landskapsmuseum.

del föremål som inte hör hemma i det ifrågavarande geografiska området, vilket beror på att man inte hade avgränsat något bestämt område under insamlingsverksamhetens tidigare skeden. Hur skall samlingen då kompletteras? Förutom täckande kunskap om samlingen behövs aktiv anskaffning. Kompletteringen förutsätter insamlingsresor, annonsering, auktionsbesök, förfrågningar, uppföljning av dödsbon, inlösningar, byte med andra museer etc. Kompletteringen förutsätter också täckande och fungerande dataregister.

\section{INSAMLINGSPROGRAM I FINLAND}

Utarbetandet av ett insamlingsprogram inleddes alltså med en enkät till landskapsmuseerna rörande deras insamlings-, forsknings- och dokumenteringsverksamhet. På basis av enkäten gjordes ett sammandrag, där varje landskapsmuseum, utgående från museets egna enkätsvar, tilldelades ett tyngdpunktsområde $\mathrm{i}$ det riksomfattande insamlings- och dokumenteringsprogrammet. Det ledde till en indelning i ansvarsområden som i stor utsträckning grundade sig på icke-kontrollerade 
och icke-specificerade uppgifter samt på museernas tidigare samlingar. Programmet uppvisar speciellt stora brister i fråga om dokumenteringen av den nära förgångna tiden och nutiden.

Museiverkets forsknings- och dokumenteringsprogram genomfördes $\mathrm{i}$ orätt ordning med tanke på den regionala insamlingsverksamheten. Enkäten gav inte klarhet $\mathrm{i}$ fråga om den regioninterna insamlings- och dokumenteringsverksamheten, utan hade tyngdpunkten lagd på landskaps- och riksnivån. När man utarbetar insamlingsprogram måste man dock utgå från den regionala nivån så, att man under landskapsmuseernas överinseende utarbetar lokala program och landskapsprogram. Och uttryckligen i denna ordning! Först ett lokalt och sedan ett landskapsprogram. Detta kan bäst genomföras så, att landskapsmuseets regionmuseiforskare leder utarbetandet av en utredning av de olika kommunernas forsknings-, dokumenterings- och insamlingsverksamhet och eventuella program. Det är viktigt att få med uppgifter om de lokala museernas samlingar, föremålsgrupper och föremålsantal. När man utarbetar lokala insamlingsprogram borde man så noga som möjligt precisera det ifrågavarande museets verksamhetsområde samt ortens särdrag och förutsättningar utgående från de existerande samlingarna. För närvarande finns det på de flesta orter mycket likartade samlingar av «stävor och skäppor» i gamla sockenmagasin. Några lokala särdrag kommer inte till synes i samlingarna. Man kan säga, att man hittar likadana museisamlingar i Österbotten och Kajanaland, i Tavastland och i Egentliga Finland. För att avhjälpa bristen på klar identitet $\mathrm{i}$ insamlingsprogrammen tog överdirektör
Henrik Lilius hösten 1995 initiativet till ny planering, som inleddes med en utredning av de lokala särdragen. Med hjälp av den hoppas man att för varje museum kunna hitta den insamlingsuppgift och det ansvarsområde som bäst beskriver museets egen verksamhetsregion.

Det nationella centralmuseets, Finlands Nationalmuseum, roll specificeras så, att museet tar till vara samlingar som är av nationell betydelse. Hit hör t.ex. samlingar som är viktiga ur centralförvaltningens synpunkt - presidenten, statsrådet, riksdagen osv. - samt arkeologiskt viktiga samlingar, en uppgift som också enligt lagen tillkommer nationalmuseet. Specialmuseerna (bilmuseet, vägmuseet, järnvägsmuseet, kanalmuseet, glasmuseet, postmuseet, telemuseet, tekniska museet, jaktmuseet etc.) sköter sina respektive områden på ett rikstäckande sätt så, att de andra museerna inte behöver fästa någon större uppmärksamhet vid dem. Den här ansvarsindelningen ger alltså landskapsmuseerna i uppgift att på bred basis sköta det insamlingsarbete som hör samman med särdragen i det egna landskapet, och de små lokalmuseerna skall åstadkomma täckande samlingar som beskriver den egna kommunens identitet.

När man försöker precisera ansvarsområdena är det säkert enklast att lyfta fram de museer som verkligen företräder de lokala särdragen inom näringslivet, det ekonomiska livet eller kulturen. Sådana museer i Egentliga Finland är åtminstone stenarbetsmuseet i Vemo, maskinverkstadsmuseet i Virmo, kvarnmuseerna i Loimaa och Lundo samt elmuseet i Pemar. Under planering är ett museum för jordbruksmaskiner i Loimaa och ett fiskerimuseum i Rimito. Fast många socknar förut- 
64 om sina särdrag har en stark jordbrukstradition, måste man framdeles noga överväga, huruvida varje socken i Egentliga Finland faktiskt behöver en samling "stävor och skäppor» eller om det räcker att några (3-4) av de starkt jordbruksdominerade socknarna $\mathrm{i}$ landskapet har en sådan medan de andra koncentrerar sig på ortens särdrag. Vid uppgörandet av insamlingsprogrammen måste man också fatta bin-

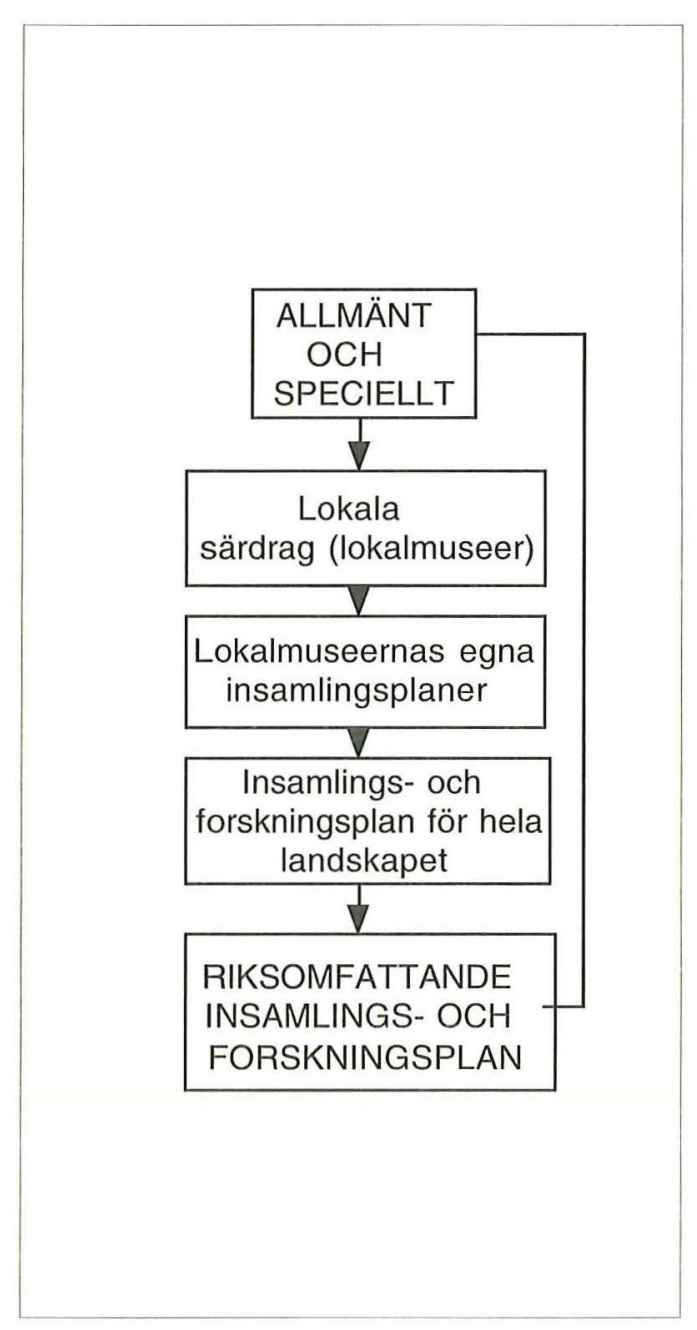

dande beslut om att inte på annat håll grunda museer med samma insamlingsprinciper ifall inte verkligt vägande kulturella eller kulturpolitiska skäl föreligger. En princip kunde också vara, att varje kommun inte behöver ha ett eget museum. Flera kommuner skulle, i enlighet med ett insamlingsprogram, kunna koncentrera sina resurser till ett enda museum, som betjänar de gemensamma intressena.

På motsvarande sätt skulle man kunna granska arbetsfördelningen mellan de olika museerna i samma kommun. Vi kan ta Åbo som ett exempel. I staden finns näs$\tan 20$ olika museer. För att effektivera insamlingen borde en gemensam plan utarbetas för hela den kommuninterna museiverksamheten, och varje museum borde få ett eget, specificerat insamlingsprogram i syfte att undvika dubbleringar. Det skulle givetvis vara förnuftigt att fördela ansvaret redan på organisatorisk nivå, så att alla de kulturhistoriska museerna skulle lyda under samma ledning, konstmuseerna skulle ha sin ledning och de naturhistoriska museerna sin. En inriktning på tillvaratagande och undersökning av föremålsbeståndet från en nära förgången tid och från nutiden kräver också nya metoder, och att utveckla dem är en av de viktigaste uppgifterna när det gäller museiarbetet i dag.

Schematiskt återgivet skulle arbetet löpa på följande sätt (se fig.).

En fördelning av ansvaret för tillvaratagandet resulterar åtminstone teoretiskt sett i täckande nationella, regionala och lokala samlingar, som kompletterar specialmuseernas samlingar från olika områden. Ett planmässigt tillvaratagande av föremål eller fenomen eliminerar också vissa etiskt 
sett besvärliga problem. Om och när museernas insamlingsarbete blir planmässigt och handlett, uppstår det endast sällan problem som gäller utgallringar och avskrivningar.

\section{SUMMARY}

On the necessity of programmes for collecting in museums

After describing the unsystematic and haphazard way in which museum collections in Finland have been brought together, the paper goes on to review ideas about collecting practices (Pearce, Jeudy, Fromm). It then discusses both the responsibility and possibility of introducing a systematic collecting programme in museums. Reference is made to the Swedish SAMDOK-project through which nation-wide cooperation between museums has been organised. The aim is to subdivide the immense field of contemporary collecting into various sections distributed among the museums. This allows the achievement of a reasonable coverage. The paper concludes by proposing a programme for systematic collecting which gives specific responsibilities to specialised museums, but endorses general collecting based on local, regional and national levels. However the analysis must then start on the local level.

In 1981 a national programme of museum policy in Finland was published. However, it failed to deal with the necessity of planned collecting arguably because it did not analyse the task properly and did not start on the local level.
NOTER

1. Museiförslag - kulturrådets överväganden och förslag angående de centrala museernas uppgifter och ansvar för landets museiväsende.

2. Hilkka Vallisaari, Tarvitseeko museo kuriositeetteja. Museo 3/1996.

3. Peter van Mensch, Museology and museums. Report of the symposium held at HelsinkiEspoo, September 1987; Jouko Heinonen Markku Lahti, Museologian perusteet (Jyväskylä 1996), s. 82.

4. Susan M. Pearce, Museums, Objects and Collections: A cultural Study (Leicester 1992), passim.

5. Heinonen - Lahti 1996, s. 76.

6. A. M. Tallgren, Museomiehen työpöydältä. Kirjoitelmia muinaistieteellisten ja antikvaaristen harrastusten historiasta Suomessa (Helsinki 1924), s. 110-111.

7. Heli-Maija Voutilainen, Opiskelijat keruutyössä - Jyväskylän seminaarin museon hieno kokoelma, s 26-29.

8. Museonhoidon opas paikallismuseoille. Esipuhe.

9. Maria Koskijoki, Keräilyn pienoismaailman historia. Museo 2/95.

10. Marketta Mäkinen, Esinebulimania. Liikaa esineitä, mikä on museokokoelmien tulevaisuus.

Museo 3/93.

11. Kerstin Smeds, Ollako vai omistaa? Aika, esine, identiteetti. Museo 1/94.

12. Smeds $1 / 94$.

13. Erich Fromm 1976

14. Smeds $1 / 94$.

15. Heinonen - Lahti 1996, s. 80.

16. Heinonen - Lahti 1996, s. 81.

17. Heinonen - Lahti 1996, s. 77.

18. Heinonen - Lahti 1996, s. 78.

19. Tallgren 1924, s. 99.

20. Undervisningsministeriets beslut om landskapsmuseer 1980.

21. Helena Honka-Hallila, Maaseudun paikallis- 
66 museotoiminta Suomessa 1900-1978. Kappale kansatieteen harrastuksen historiaa. Turun yliopisto. Suomalaisen ja vertailevan kansatieteen pro gradu-työ 1980, s. 12.

22. Museopoliittinen ohjelma (Museipolitiskt program) 1981, s. 17-18; Alexander Fenton,

Collections research: local, national and international perspectives. Collections Management. Edited by Anne Fahy. London 1995), s. 227230; J. Kenyon, Collecting for the twenty-first century. Collections Management. Edited by Anne Fahy (London 1995), s. 122-125.

23. Museopoliittinen ohjelma (Museipolitiskt program) 1981, s. 25-26.

24. Museopoliittinen ohjelma (Museipolitiskt program) 1981, s. 30.

25. SAMDOK - Nykyajan dokumentoinnin ohjelma. Suomen museoliitto tiedottaa 5/1982; ks. myös Alexander Fenton, Collection research: local, national and international perspectives. Collections Management, edited by Anne Fahy, London 1995, s. 227-230, Rosander 1976, s. 7075.

26. Rosander 1976, s. 71-72.

27. Rosander 1976, s. 72.

28. Janne Vilkuna, Ottaa vaiko jättää. Museo 3/93.

29. Museopoliittinen ohjelma (Museipolitisk program) 1981, s. 10.

Juhani Kostet är direktör för museiväsendet vid Abo landskapsmuseum och docent $i$ Finlands historia vid Universitetet $i$ Uleåborg.

Adr. Fiskaregatan 4 FIN-20100 Abo

Fax. +358-2-2620444

epost: juhani.kostet@turku.fi 